\title{
Hungarian Cookbooks for Israeli Readers: A Comparative Literary- Cultural Analysis
}

\section{Ilana Rosen}

\begin{abstract}
How long and how strong is Diasporic memory? How many generations can it encompass? How deeply can generations that never lived in the old country relate to its landscape, language, colors and tastes? In the case of Israelis of Hungarian origin, these questions inevitably have to do with the history of Hungarian Jews in the late nineteenthand early-to-mid twentieth-century, with a focus placed more acutely upon World War II and the Holocaust. Written by a female Israeli researcher of folk and documentary culture who belongs to the second-generation of Hungarian-Jewish Holocaust survivors, the present article strives to deal with the foregoing and other relevant questions through a comparative literary-cultural analysis of the only two presently existing Hebrew-language Hungarian cookbooks. These two cookbooks were published in Israel in 1987 and 2009, respectively, by two male cultural celebrities, the first by a Hungarian-born journalist, author and politician and the second by an Israeli-born gastronomer and grandson of Hungarian-Israelis.
\end{abstract}

Keywords: Cookbook, alimentary life writing, Hungarian-Israelis, Holocaust, Yosef Tommy Lapid, Ofer Vardi

Biography: Ilana Rosen, of the Department of Hebrew Literature at the Ben Gurion University of the Negev, is a researcher of folk and documentary literature of Jews and Israelis in the twentieth century. Her last study, Pioneers in Practice: An Analysis of Documentary Literature by Veteran Residents of the Israeli South, was published in 2016 by the Ben Gurion Institute for the Study of Israel and Zionism. Since 2013 she has been the Book Review Editor of Hungarian Cultural Studies. ilanaro@bgu.ac.il

How long and how strong is Diasporic memory? How many generations can it, or should it, encompass? How deeply can generations that never lived in the old country relate to its landscape, language, colors and tastes? Written by a female Israeli researcher of folk and documentary culture who belongs to the second-generation of Hungarian-Jewish Holocaust survivors, this article attempts to examine these and other relevant questions through a comparative cultural analysis of the only two, extant Hebrew-language Hungarian cookbooks. (Although there are or may be more such books or booklets, these sources are far from being carefully prepared or easily attainable). The two cookbooks were published in Israel in 1987 and 2009 by two male cultural celebrities; the first by Yosef/Joseph Tommy Lapid, a Hungarian- 
Rosen, Ilana. "Hungarian Cookbooks for Israeli Readers: A Comparative Literary-Cultural Analysis." Hungarian Cultural Studies. e-Journal of the American Hungarian Educators Association, Volume 13 (2020) DOI:

born journalist, author and politician and the second by the gastronomer and cookbook publisher, Ofer Vardi, an Israeli-born grandson to Hungarian-Israelis.

In a rigorous state-formation setting like that of the young state of Israel in the 1950s and 1960s, wherein the new society (re-)constructs its culture by resurrecting its ancient traditions and creating new indigenous ones while simultaneously devaluating the shorter-term memories of its many newly-arrived immigrant groups, these memories might, indeed, quickly fade away or altogether disappear along with their original bearers. Yet, in more recent world-wide settings of globalization, multi- and trans-culturalism, including present-day Israel, these dynamics have considerably weakened (Castles; Wimmer and Schiller; Kimmerling; Raviv; Avieli) and thus enabled a resurrection or reconstruction of the memories of the immigrants' old countries. Alas, as is true in the Israeli case, by this time the original bearers of old memories have already died, leaving their children without even a proper command of the language of the old country, in this case Hungary, not to mention cherishing the customs and traditions of the previous, Diasporic generation. In two recent articles I devoted to the prose works and poetry of the 1.5 generation (as defined by Susan Rubin Suleiman) and second-generation Israeli descendants of Holocaust survivors of Hungarian origin, I showed that these authors emphatically explore their Hungarian family-histories, the Holocaust and the destruction of their older generations in their works. Yet when it comes to the authors' own use and command of Hungarian, what they actually have is only fragments of their Hungarian past (Rosen 2014, 2015).

It naturally or reasonably follows that when we arrive at the third generation of Immigrants of Hungarian origin (who could theoretically be the children of the authors I studied) they have even fewer connections to their roots compared to their previous generations. A quick and informal survey I recently carried out among such people within my work, social and family environments that comprised a dozen men and women in their twenties to their forties, yielded the results that individuals of the third-generation Hungarian-Israelis hear Hungarian in the sense of being able to recognize it, or that it sounds familiar and familial to them even if they far from understand what they hear. They may remember the Hungarian names of dishes, ingredients, home objects or clothing they heard from their previous generations. More often than not, they remember some words and expressions, scraps of children songs and rhymes, and swear words as used by the older generations. They may like and even cling to the taste of a certain dish, say madártej ['birdmilk,' a vanilla custard with a poached meringue on top, a dessert that is actually a variant of French oeuf à la neige or île flottante, which have equally picturesque if totally different meanings: 'snowy egg' and 'floating island'], or they may express apathy or aversion to the strange flavor of the same dish. This is about all. These third-generation individuals may, of course, also have lively memories of their recent touristic trip to Budapest and its lovely ruin-pubs, but those very fresh memories belong in their sensibilities to entirely different realms than their old, savored or derided Hungarian family roots or second-hand reminiscences.

On the face of this not entirely promising inventory of Hungarianism among present-day young Israelis of Hungarian origin, it is surprising and heartening to discover a recent Hebrewlanguage Hungarian cookbook, one of the only two of its kind within a multi-culture that has produced many Diasporic or country-of-origin cookbooks. Entitled Goulash lagolesh - matamei hamitbah hahungari ['Goulash for the Browser: Delicacies of the Hungarian Kitchen'], this cookbook was created by Ofer Vardi (b. 1973), a food journalist and the present owner of a 
Rosen, Ilana. "Hungarian Cookbooks for Israeli Readers: A Comparative Literary-Cultural Analysis.” Hungarian Cultural Studies. e-Journal of the American Hungarian Educators Association, Volume 13 (2020) DOI:

recipe and lifestyle press called LunchBox [sic] (Vardi 2009). Vardi is the grandson of a couple who left Hungary with their only son Joseph, then aged nine, following the 1956 Uprising; in early 1957 they landed in the new town of Beer Sheva in southern Israel. About a decade later, their son Joseph met and married Rivka Weiss who, like himself, came from a Hungarian-Israeli family and they had Ofer and another, younger son. Judging by the various holiday, lifecycle and pastime events depicted in the many pictures decorating Vardi's book, he grew up enjoying the Hungarian cuisine of both his Hungarian grandmothers, the Beer Shevite Rozsi Vardi, whom he calls Nana, and his other grandmother, Ilkele Weiss, who lived in the southern countryside and at whose home he therefore spent less time than with the Vardis. (It should be mentioned that back in Hungary the family's name had been Váradi, but due to some disruption somewhere on their way or upon their arrival to Israel their last name lost its middle vowel).

After his Grandma Rozsi's death in 2001, Ofer Vardi found - or rather realized the value of-her Hungarian recipe notebook. This source gave him the idea of creating a Hebrew version of the recipes inside, which he first published in a series of annotated recipes in an Israeli gastronomy journal, then in a widely-read newspaper, both on-line. Finally, the collection appeared in a graphically and pictorially very elegant, card-box shaped cookbook. The book box contains some ninety cards sized 5.8 by 8.3 inches each. One side of each card relays the dish's history or story, whether in Hungary, sometimes going back to the Habsburg Era, or in the humble Israeli homes of the Vardis or the Weisses. The other side features the recipe and photograph of the dish. A given story might be about what Austro-Hungarian Empress Erzsébet thought and may or may not have said about her daughter-in-law Princess Stefánia, or it could be about Grandma Rozsi's weekly shopping rounds to the Beer Sheva City Market.

Vardi's book is impressive and exceptional in its form and content, starting from the high quality photos of its dishes and the nostalgically blurred pictures of his 1970s and 1980s threegenerational extended family, to the careful research behind each dish, for which the author spent a year in Budapest while additionally consulting the Hungarian Chef Péter Siklósi. The book's adaptation to Israeli ingredients and standards, like the demands of kosher food custom for Hungarian-Hungarian dishes added to Grandma Rozsi's collection following Vardi's trip to Budapest or the author's recounting of many a piquant story about Hungarian rulers, warriors, noblemen, writers and chefs are all aspects that definitely deserve mention. In his cultural coverage alone, Vardi could compete with the author of the other, older Hebrew Hungarian cookbook discussed in this article, namely, the late journalist, author and politician Yosef/Joseph Tommy Lapid, né Tomislav Lampel, who was born in 1931 in Novi Sad or Újvidék (once part of Austro-Hungary, then of inter-war Yugoslavia, then of World War II Hungary and presently in Serbia) and died in Tel Aviv in 2008.

Lapid's cookbook, Paprika - kakha mevashlim hahungarim ['Paprika: This Is How the Hungarians Cook'], was published in 1987 by the R. Sirkis cookbook and lifestyle press. Edited by Ruth Sirkis, the owner of the press, co-author of the book and a known cooking celebrity to this very day, as in Vardi's book the recipes were adapted to meet kosher food-custom demands (Lapid and Sirkis, henceforth L\&S). Though less extravagant than Vardi's work, Lapid's book is also graphically impressive, with many black and white illustrations (drawn by Gil Elkabetz) of traditionally dressed cooks and bakers, both peasants and urban or professional ones, toiling laboriously on their dishes or celebrating them. Although to a lesser extent than in Vardi's book, Lapid's book is additionally laced with stories and anecdotes of the author's life experiences and 
Rosen, Ilana. "Hungarian Cookbooks for Israeli Readers: A Comparative Literary-Cultural Analysis." Hungarian Cultural Studies. e-Journal of the American Hungarian Educators Association, Volume 13 (2020) DOI:

family histories since his childhood in Újvidék of the 1930s up to his life of several careers in Israel of the mid-late twentieth century (for analogous English-language Hungarian cookbooks, see: Radke; Körner; Kirsche Shapiro).

Based on the general portraits of the two Israeli Hungarian cookbooks and those of their authors, as well as on the understanding that cookbooks are never just lists of recipes but also cultural products and culture preservers (Mitchell; Abala), I now proceed to a close comparative analysis of the two cookbooks. Mainly, I shall ask and offer answers to these questions: What kind of Hungary is imagined-in Benedict Anderson's sense of "imagined communities," meaning groups sharing a corpus of ideas uniting them and distinguishing them from others (Anderson; Manur 2007, 2010) - in each of these two cookbooks? Which periods and events in Hungarian history are stressed and which times and issues are suppressed or barely glimpsed in each book and why? What parts of the two cookbooks are specifically Jewish, or even Israeli? Lastly, in what senses are these two cookbooks also powerful, multi-sensory personal, familial and communal sites of memory and longing, whose proof lies not only in their puddings but also, if not more so, in their hindsight prudence? Inevitably, most if not all of these questions have to do with the history of Hungarian Jews in the late nineteenth- and early-to-mid twentiethcentury, and more acutely in World War II and the Holocaust of Hungarian Jews.

In her "Introduction to and Bibliography for the Study of Alimentary Life Writing and Recipe Writing as War Literature," Louise O. Vasvári traces the view of alimentary life-writing as cultural creation back to the early 1900s work of German Sociologist Georg Simmel (18581918). As she shows, from Simmel on many other researchers throughout the twentieth century explored the importance of food, food practice and discourse as a meeting area of history, culture and tradition, as well as between the individual and the community or the communal. With its voluminous events of conflict, willful and forced migration, building and ruin of nations and societies, as well as the gradually growing integration of women into central arenas of society, the century that ended not long ago supplies cultural researchers with many examples of powerful alimentary documents. These works range from war diaries and memoirs offering telling accounts of food management in extreme conditions, to forms of gastrography, i.e., personalized cookbooks or alimentary life writing, by chefs and food journalists (Vasvári, "Introduction"). The two cookbooks discussed in this article belong in this very last category; as such they are just as formal or stylized as they are personal, familial and communal. In addition, they are overtly and intentionally commercial(ized) products meant to publicize and enrich their business- and culture-entrepreneur authors. These authors wish to reminisce and pass on familial and communal knowledge and also offer and find some consolation regarding their Holocaustrelated losses (see further in the same $C L C W e b$ volume Vasvári's survey and analysis of a large corpus of alimentary life-writing by women Holocaust-survivors: Vasvári, "En-gendering Memory;" Vasvári, "Nem és emlékezet;" ['Gender and Memory'] Vasvári, "Identity and Intergenerational Remembrance," which is specifically about Hungarian women; Hirsch and Spitzer).

The cookbooks by Lapid and Vardi both follow a standard structure of starting with appetizers and first courses or soups, then main dishes made of kosher meats of all sorts (e.g., goose or its fat as replacement for pork products in non-Jewish Hungarian dishes) accompanied by vegetable or grain side-dishes, then last courses and pastries and so on. In addition, Vardi adds a last section devoted to the Jewish yearly holiday cycle, wherein he lists dishes that could 
Rosen, Ilana. "Hungarian Cookbooks for Israeli Readers: A Comparative Literary-Cultural Analysis." Hungarian Cultural Studies. e-Journal of the American Hungarian Educators Association, Volume 13 (2020) DOI:

be attached to a certain Jewish holiday. This list is deliberately non-traditional but rather novel in that, for example, for hanukkah it offers not the routinely expected potato-kremzli, or latke, but rather a recipe for lángos, a fried round of yeast dough that Vardi likens to a YemeniteIsraeli, pita-shaped pastry called malawah in Hebrew and Arabic (Vardi 73-90). He then concludes this list with his grandmother's special offer for her grandchildren's birthdays, when they could choose between a dark-brown, chocolate cake and one with a white cream, which due to a poor command of Hebrew she mistakenly (and amusingly for an Israeli ear) called lavan uga meaning "cake white" instead of "white cake" (Vardi 90).

It is interesting to note that both authors hardly give any significant space in their books to female figures, except, of course, that Vardi does to his own grandmother/s. In addition, while Lapid features no notable women, in his book he constantly uses phrases such as: "any housewife who respects herself" or "this is just the dish that a man coming home on a cold winter evening expects his wife to serve him" (L\&S 36, 43, 53, 54, 94, 99, 102 and more). Thus Lapid's book comes close to some of the case studies in Jessamyn Neuhaus's Manly Meals and Mom's Home Cooking in its image or portrayal of the "man in the kitchen," who far from cooking everyday meals either cooks gourmet ones or feels lost trying to cook any meal at all (Neuhaus; Zafar). As we shall see, in Vardi's book too, beyond honoring the author's late Grandmother Rozsi Nana and, to a lesser extent, his Grandmother Ilkele, the overall attitude to women's cooking is close to that in Lapid's book, despite the distance of over twenty years between the publication of the two books and the age difference of over forty years between the two authors.

As is customary for many a Hungarian cookbook and nowadays also for many Internet recipe-sites, oftentimes a dish's name may connect it to a Hungarian place-name, such as a city/town, region, or river, or to a known personage. It is therefore interesting to examine the appearance and distribution of places and personages in the two books at hand and thus possibly chart the map of longing for the past homeland of the two authors and/or their respective families. In Lapid's book, the imagined locale of the recipes and the explanations and stories accompanying some of them is the former Greater Hungary and, to a lesser extent, interwar Hungary, including both the author's somewhat remote hometown of Ujvidék, his trips as a child and his lawyer father's business journeys to the big city of Budapest. (Lapid resumed and further developed the latter practice in the 1970s, when he prepared a series of world-wide Hebrew tourist-guides entitled The Lapid Guide to... based on his own man-of-the-world journeys and experiences). Accordingly, Lapid's book evokes the country's past geographical vastness and demographic variety of populations with their traditions and styles. In addition, it features a whole array of the country's people of "long ago," ranging from majestic, noble and aristocratic figures, through minorities like Roma/Gypsy people. Interestingly, his overview contains no Jews, whom he apparently considers part of the general Hungarian society, but does extend to foreigners like Turks and Londoners and ends with quite a few famous Hungarian and Central-European chefs and confectioners.

To illustrate the components that make up Lapid's imagined Hungary, the following is a full rendering of the recipes representing the richness of places, people and cultures in his cookbook. Recipes invoking place names are: Szegedi halászlé ['Szeged fish soup'] (L\&S 40) and Szegedi gyulás csirke ['Szeged chicken goulash/stew'] (L\&S 93), Székelygulyás ['Szekler goulash/stew'] (L\&S 64), Hortobágyi rostélyos ['Hortobágy steak'] (L\&S 70), Erdély zsivány 
Rosen, Ilana. "Hungarian Cookbooks for Israeli Readers: A Comparative Literary-Cultural Analysis." Hungarian Cultural Studies. e-Journal of the American Hungarian Educators Association, Volume 13 (2020) DOI:

pecsenye ['Erdély gangster/bandit roast'] (L\&S 75), Kolozsvári rakott káposzta ['Kolozsvár layered cabbage'] (L\&S 78), Szabolcsi töltott káposzta ['Szabolcs stuffed cabbage'] (L\&S 83), Tiszai paprikás ponty ['Tisza peppered carp'] (L\&S 122), Bácskai mákos gombóc ['Bácska poppy-seed dumplings'] (L\&S 159), Pozsonyi kindli or beigli ['Pozsony beigels'] (L\&S 190) and several kinds of Linzer cakes and pastries named after the northern-Austrian city of Linz (L\&S 185, 189, 192, 239). Presently about half of these places belong to Hungary's neighboring countries, and this has been so since the 1920 Trianon Treaty following World War I, excluding the years of World War II when they were re-ceded to Hungary in return for its participation in the Nazi Axis. Yet, in Lapid's late 1980s recollection of his childhood inter-war Hungary, these places are part of his past homeland.

Recipes named after majestic and noble or aristocratic figures in Lapid's cookbook are the following: Mátyás ponty ['(King) Mátyás carp"] (L\&S 125) and Mátyás Király módra bélszin ['King Mátyás style sirloin'] (L\&S 68), Stefánia sült ['(Princess) Stefánia roast'] (L\&S 76) and Stefánia torta ['(Princess) Stefánia cake'] (L\&S 209), Eszterházy rostélyos ['Eszterhazy steak'] (L\&S 74), and Falffy metélt ['Falffy egg noodles'] (L\&S 149). Needless to say, these personages and all that they stand for belong to the country's Imperial past, not the author's childhood and youth in the interwar period. Recipes referring to exotic minorities or foreigners are the following: Rigó Jancsi torta (a pastry named after the Hungarian Romani/Gypsy masterviolinist, 1858-1927; L\&S 206), Török lepény ['Turkish pie'] (L\&S 192), Londoni szelet ['London slice'] (L\&S 194), and Indiáner Torta ['Indian cake'], a kind of brown, chocolate cake (L\&S 199). The last category contains recipes named after famous chefs and confectioners: Gerbeaud szelet ['slice'] named after the renowned Swiss confectioner Emil Gerbeaud (18541919) (L\&S 231), Kugler torta, a cake named after Henrik Kugler (1830-1905, L\&S 208) of Vienna, Sacher torta (L\&S 210), and Pischinger torta (https://www.pischinger.at/en/aboutpischinger, L\&S 211), with all three named after Viennese confectioners. Finally comes Dobos torta, a round cake topped by hardened caramel, whose name playfully alludes to the Hungarian word dob, meaning 'drum,' that was devised by confectioner József C. Dobos [lit. 'drummer'] (1847-1924) (L\&S 212).

Compared to Lapid's book, in Vardi's book there are far fewer recipes named after Hungarian place-names. The places that do appear are all located in the post-World War II Hungary, such as the Hortobágyi palacsinta ['Hortobágy pancake'] (Vardi 39), about which the author adds that it was first made in 1915 by the chef of the Aranybika ['Golden Bull'] Grand Hotel of Debrecen, in the country's east. Of all majestic figures the Vardi book features only a vagdalt ['meatloaf'] named after Princess Stefánia (while, as aforesaid, Lapid ascribes a sült, meaning a roast, and a cake to this figure). In Vardi's book this recipe is accompanied by the anecdote that Empress Erzsébet (1837-1898), the mother-in-law of Princess Stefánia (18641945), who had made this match for her son Prince Rudolf (1858-1889) in the first place, nevertheless disliked her Belgium-born daughter-in-law and even called her an "ugly elephant" (Vardi 25). This sole and somewhat bathetic reference to royal figures may attest to the author's remoteness from such glory symbols of the past, as well as to a similar attitude on the part of his Hungarian coeval colleagues, like Chef Siklósi whom he consulted while composing his 2009 cookbook.

Hungarian nobility is represented in Vardi's book by an Eszterházy torta (Vardi 63); the author sprinkles the cake's preparation instructions with the true (hi)story of how under 
Rosen, Ilana. "Hungarian Cookbooks for Israeli Readers: A Comparative Literary-Cultural Analysis." Hungarian Cultural Studies. e-Journal of the American Hungarian Educators Association, Volume 13 (2020) DOI:

communism names of Hungarian personages were banned from the public arena and, for example, Eszterházy utca ['street'] was renamed after the Russian poet, Alexander Pushkin. Then, following the 1989-1990 collapse of communism in the country and the entire region, the Hungarians more than happily renamed their public places after Hungarian figures (Palonen). The Vardi book also features dishes named after a few Hungarian authors and actors, sectors that are less present in Lapid's book, such as Jókai bableves ['bean soup named after writer Mór Jókai' (1825-1904)] (Vardi 8), Petôfi rostélyos ['steak named after poet Sándor Petőfi' (18231849)] (Vardi 24), and Újházi tyúkhúsleves ['chicken soup named after actor Ede Újházi' (1841-1915)] (Vardi 9, L\&S 46). As for minorities and foreigners, quite similarly to Lapid's book (although with neither a London cake nor a Turkish pie), Vardi's book has recipes for Rigó Jancsi (Vardi 60) and Indiáner (Vardi 69) cakes. Last, similarly to Lapid's book, Vardi's book features quite a few cooking and baking masters whose names have long become known rather as names of famous dishes. These include: Gundel palacsinta ['pancake'], named after both father Johann Gundel (1844-1915) of Germany, who moved and settled in Hungary, and his son Károly Gundel (1883-1956), who succeeded the baker dynasty in the new country (Vardi 52); Gerbeaud cake (Vardi 62); Dobos cake (Vardi 61); and pastries named after the twentiethcentury confectioner János Rákóczi (1897-1966), whose last name is often confused, Vardi tells us, with that of Hungarian leader and freedom fighter Ferenc Rákóczi (1676-1735), who lived two centuries earlier (Vardi 71).

Considering Jews in Vardi's Hungarian cookbook, the only reference to (Austro) Hungarian as opposed to Israeli Jews - excluding his scanty reference to the fate of Hungarian Jews in the Holocaust, an issue I discuss below in more detail - is a legend about how even the strict Chief Rabbi Moshe Hatam Sofer (1762-1839) of Pozsony/Pressburg (presently Bratislava in Slovakia) had to come to terms with his flock's habits of preparing their food and serving or eating their meals. This legend has it that he had to put up with the local practice of stuffing goose and running the risk of bruising the animal's throat and rendering it un-kosher for slaughter; or with his people's habit of soaking their Passover matzo in tejeskávé ['milk-coffee'] and thus possibly letting the matzo ferment, which is forbidden in Passover. Yet, allegedly, because he overlooked these issues, he was repeatedly re-elected, as he actually was time and again (Vardi 17). The message of this story in its framing in the book as a whole is that Hungarian Jews of the past may have had their inner, perhaps to external eyes trifle conflicts, but otherwise they were an integral and harmonious part of the Hungarian nation.

As expected from two cookbooks that are also partly life-writing works by descendants of mid-twentieth-century Hungarian-Jewish families who were persecuted and often murdered in the Holocaust of Hungarian Jews, each of the two books also has its Holocaust-related, so-called "ghost chapters," to use this term as meant by Umberto Eco in his The Role of the Reader (Eco, 204). This term means that some information, content and messages may not be explicitly pronounced in the work, or they are there, but only fleetingly; and therefore we as the work's implied and informed readers realize just how much these things matter to the author despite or exactly because of their scarce mention. Joseph Tommy Lapid has described time and again the moment he lost his faith in God at the sight of his father, Advocate Dr. Béla Meir Lampel, being literally wrenched out of their home on March $19^{\text {th }}, 1944$, the very date the Nazi-German invasion entered Hungary with the intention of activating the Final Solution on the country's Jews (Braham). Lapid's father was first imprisoned in the nearby Bácska internee camp, then 
Rosen, Ilana. "Hungarian Cookbooks for Israeli Readers: A Comparative Literary-Cultural Analysis." Hungarian Cultural Studies. e-Journal of the American Hungarian Educators Association, Volume 13 (2020) DOI:

transferred to Auschwitz and finally to Mauthausen, where he died of heart failure two weeks before liberation.

Over forty years after Lampel's death, when his son Lapid composed his Hebrew Hungarian cookbook probably wishing to leave behind him a culinary tradition as well as, more generally, the image of upper-class Central-European Jews of the past like his father, the cookbook was hardly the stage for delineating his personal and family Holocaust-related tragedy. Yet in his book the son repeatedly foregrounds his father as a well-rooted, eminent Austro-Hungarian lawyer and proud Zionist, as well as an overweight man who loved life and his family and who, for example, enjoyed watching, discussing and even participating in eating contests (L\&S 108, 156, 182). Lapid's father, reduced to a ragged man dying in Mauthausen, could not have been but the shade of the robust man, the husband who eschewed the strict diet his wife had worriedly imposed on him. The father would sneak with their son, Tommy, to the town's Mária Restaurant to enjoy Szalóntüdö ['Salon lungs'] (an oxymoron of sorts because lungs were the cheapest meat yet when made in wild-game style with sour cream and served in an elegant restaurant they became a delicacy), while treating little Tommy to two sausages to ensure his silence back home (L\&S 8, 77). Following in his father's footsteps in many ways, the son was able to recreate in his Hebrew Hungarian cookbook the spirit of the world in which the father had once lived and mostly enjoyed and loved. (Just as inventively, this time using the tricky convention of creating a dead person's memoirs after his death, did Yair Lapid, the grandson, an Israeli journalist, writer and politician in his own right, manage to enliven the colorful and sometimes provocative figure of his father in his Memories After My Death: The Story of Joseph "Tommy" Lapid).

In the case of Ofer Vardi's card-box cookbook, because the Vardis left Hungary soon after and under the shadow of the 1956 Uprising, it appears throughout the book that for this author the ultimate evil is the reign of communism and the Soviet Union in Hungary following world War II, rather than the Nazi-German inspired Hungarian pro-Fascist regime and its persecution of the country's Jews. It is only toward the very end of his book that Vardi parsimoniously refers to his Grandmother Rozsi's life in Budapest of 1944-1945, and he narrates her horrific experience of barely escaping a shooting raid by some "armed Hungarians" while hiding in one of the Swedish Protected Houses in the city (Vardi 84). Otherwise, in the two pages that he devotes to the fate of Hungarian Jews in the Holocaust, Vardi more often identifies the perpetrators as "the Nazis" or "the Nazis and their helpers" (84-85), which comes close to present-day official Hungarian formulations on memorial columns, plaques and in some Hungarian museums (Szücs).

To conclude, in this article I examined two Hebrew-language Hungarian cookbooks that exist today, one from 1987 and one from 2009. The first was composed by a 1.5 generation Holocaust-survivor immigrant from Újvidék/Novi Sad who became a political and cultural authority and celebrity in Israel of the closing decades of the twentieth century. The second was written by a gastronomer and cookbook author, a grandson to 1956 immigrants from Budapest. Both books are luxurious artifacts and memory sites hailing the coexistence of Christians and Jews in Hungary for close to a thousand years. Because the aim of both authors is to glorify the shared past of the two groups rather than dwell on the dark years of the early-mid 1940s, in their books both stress the positive and pleasant sides of the two groups' togetherness; not to mention the ties that each author has created with present-day Hungarian culture, touristic and culinary 
Rosen, Ilana. "Hungarian Cookbooks for Israeli Readers: A Comparative Literary-Cultural Analysis." Hungarian Cultural Studies. e-Journal of the American Hungarian Educators Association, Volume 13 (2020) DOI:

10.5195/ahea.2020.392

culture included. Yet, both authors, each in his own timely moment/s of reconnaissance-or anagnorisis, to cite the poetics of ancient Greek stage drama - also turn their gaze back onto the black hole of the Holocaust of Hungarian Jews. Thus, both authors do incorporate, albeit mostly implicitly, in their merry Hungarian cookbooks some gestures of commemoration to their family members who fell victim to the Hungarian Holocaust. In today's Hungary the foodways of the past are alive and brewing or sizzling as ever if not even more, but for former Hungarian-Jews and present Israelis of Hungarian origin (as probably for all other Jewish and gentile HungarianDiasporas), these foodways have to be remembered and re-minded whether through everyday or special-day practice, or by notes like those in Grandma Rozsi Nana's stained notebook. An even better method for future preservation and use is by turning to colorful and tasteful works like the two cookbooks explored throughout this article.

\section{Works Cited}

Abala, Ken. "Cookbooks as Historical Documents," The Oxford Handbook for Food History. Ed. Jeffrey M. Pilcher. Oxford and New York: Oxford Handbooks Online, 2012.https://books.google.co.il/books?hl=iw\&lr=\&id=KDNpAgAAQBAJ\&oi=fnd\&pg=P P1\&dq=Pilcher,+oxford +handbook+for+food+history\&ots=Xoqjr_sC5e\&sig=8qY8TrBSn VN5fgr4kwRC65sbPWo\&redir_esc=y\#v=onepage\&q=Pilcher\%2C\%20oxford\%20handbo ok\%20for\%20food\%20history\&f=false.

Anderson, Benedict. Imagined Communities: Reflection on the Origin and Spread of Nationalism. London and New York: Verso, 1991 [1983].

Avieli, Nir. Food and Power: a Culinary Ethnography of Israel. Oakland, CA: U of California P, 2018.

Braham, Randolph L. and Scott Miller, eds. The Nazis' Last Victims: The Holocaust in Hungary. Detroit: Wayne State UP, 1998.

Castles, Stephen. "Migration Community Formation under Conditions of Globalization," International Migration Review IMR, 36:4, 2002, 1143-1168.

http://onlinelibrary.wiley.com/doi/10.1111/j.1747-7379.2002.tb00121.x/full.

Eco, Umberto. The Role of the Reader. Bloomington and London: Indiana UP, 1979.

Hirsch, Marianne and Leo Spitzer. "Testimonial Objects: Memory, Gender and Transmission," Poetics Today 27:2, 2016, 353-383.

Kimmerling, Baruch. The Invention and Decline of Israeliness: State, Culture and Military in Israel. Los Angeles and Berkeley, CA: U of California P, 2001.

Kirsche Shapiro, Lynn (ed. Nancy Ross Ryan). Food, Family and Tradition: Hungarian Kosher Family Recipes and Remembrances. UK: Cherry Press, 2014.

Körner, András. A Taste of the Past: The Daily Life and Cooking of a NineteenthCentury Hungarian Jewish Homemaker. Hanover: UP of New England, 2004.

Lapid, Yosef Tommy and Ruth Sirkis. Paprika - kakha mevashlim hahungarim ['Paprika: This Is How the Hungarians Cook']. Tel Aviv: R. Sirkis, 1987.

Lapid, Yair. Memories after My Death: The Story of Joseph “Tommy” Lapid. New York: Thomas Dunne Books, 2011 [Heb. 2010]. 
Rosen, Ilana. "Hungarian Cookbooks for Israeli Readers: A Comparative Literary-Cultural Analysis.” Hungarian Cultural Studies. e-Journal of the American Hungarian Educators Association, Volume 13 (2020) DOI:

10.5195/ahea.2020.392

Manur, Anita. "Culinary Nostalgia: Authenticity, Nationalism and Diaspora," Multi-Ethnic Literature of the Unites States MELUS 32:4, 2007, 11- 31.

----. Culinary Fictions. Philadelphia, PA: Temple University Press, 2010.

Mitchell, Janet. "Cookbooks as a Social and Historical Document: A Scottish Case Study," Food Service Technology 1:1, 2001, 13-23. http://onlinelibrary.wiley.com/doi/10.1046/j.1471-5740.2001.00002.x/full.

Neuhaus, Jessamyn. Manly Meals and Mom's Home Cooking: Cookbooks and Gender in Modern America. Baltimore, MD: Johns Hopkins UP, 2003.

Palonen, Emilia. "The Politics of Street Names: Local, National, Transnational Budapest," Local Memories in a Nationalizing and Globalizing World, eds. Marnix Beyen and Brecht Deseure. UK and New York: Palgrave Macmillan, 2015, 51-66.

Radke, Linda F. That Hungarian in My Kitchen: 125 Hungarian American Kosher Recipes. Arizona: Five Star Publications, 1990.

Raviv, Yael. Falafel Nation: Cuisine and the Making of National Identity in Israel. Lincoln NEB and London: U of Nebraska P, 2015.

Rosen, Ilana. "Fragments of a Hungarian Past in the Literature of 1.5 and Second Generation Austro-Hungarian Immigrants in Israel," Hungarian Cultural Studies HCS 7, 2014, 41-53. https://ahea.pitt.edu/ojs/index.php/ahea/article/view/138/191.

-----. "The Poetry of 1.5 and Second-Generation Israelis of Hungarian Origin," Hungarian Cultural Studies HCS 8, 2015, 4662.https://ahea.pitt.edu/ojs/index.php/ahea/article/view/218/325.

Suleiman, Susan Rubin. "The 1.5 Generation: Thinking about Child Survivors and the Holocaust," American Imago 59:3, 2002, 277-295. https://muse.jhu.edu/article/182/pdf.

Szücs, Teri ed. Bevésett nevek. Konferenciakötet ['Engraved Names: Conference Proceedings']. Budapest: Eötvös Loránd Tudományegyetem ELTE, 2015.

Vardi, Ofer. Goulash lagolesh - matamei hamitbakh hahungari ['Goulash for the Browser: Delicacies of the Hungarian Kitchen']. Tel Aviv: LunchBox, 2009 [iPhone English edition: Going Paprikash: The Best of Hungarian Jewish Cuisine, 2011].

Vasvári, Louise O. "Introduction to and Bibliography for the Study of Alimentary Life Writing and Recipe Writing as War Literature," CLCWeb: Comparative Literature and CultureLife Writing and the Trauma of War 17, 2015, 1-8. https://docs.lib.purdue.edu/cgi/viewcontent.cgi?article=2781\&context=clcweb.

-----. "En-gendering Memory through Holocaust Alimentary Life Writing," CLCWeb: Comparative Literature and Culture - Life Writing and the Trauma of War 17, 2015, 1-8. https://docs.lib.purdue.edu/cgi/viewcontent.cgi?article=2721\&context=clcweb.

-----. "Nem és emlékezet a táplálkozási élettörténet-írásokban a holokauszt idején és után" ['Gender and Memory in Alimentary Life Writing in the Holocaust and After'], Múlt és Jövö ['Past and Future'] 2016:4, 104-140.

http://www.multesjovo.hu/en/aitdownloadablefiles/download/aitfile/aitfile_id/ 2813.

-----. "Identity and Intergenerational Remembrance through Traumatic Culinary Nostalgia:Three Generations of Hungarians of Jewish Origin," Hungarian Cultural Studies HCS 11, 2018, 57-77. https://ahea.pitt.edu/ojs/index.php/ahea/article/view/322/630 
Rosen, Ilana. "Hungarian Cookbooks for Israeli Readers: A Comparative Literary-Cultural Analysis." Hungarian Cultural Studies. e-Journal of the American Hungarian Educators Association, Volume 13 (2020) DOI:

10.5195/ahea.2020.392

Wimmer, Andreas and Nina Glick Schiller. "Methodological Nationalism and Beyond: NationState Building, Migration and the Social Sciences," Global Networks 24:2, 2002, 301-334. http://onlinelibrary.wiley.com/doi/10.1111/1471-0374.00043/full.

Zafar, Rafia. "The Signifying Dish: Autobiography and History in Two Black Women’s Cookbooks," Feminist Studies 25:2, 1999, 449-469.

http://www.jstor.org/stable/pdf/3178690.pdf?refreqid=excelsior:f67203ea027f5f3dafed9c77707 084e5. 